\title{
TRE ISLAMIC MICRO-FINANCE PROGRAMME AND ITS IMPACT ON RURAL POVERTY ALLEVIATION ${ }^{1}$
}

\author{
M. Miazur Rahman \\ Islami Bank Bangladesh Ltd (IBBL), Bangladesh
}

\begin{abstract}
Bangladesh launched a shari'ah based micro-finance programme in 1995 under the Rural Development Scheme to uplift the overall socioeconomic standards of rural poor. It covered 0.52 million group members, $94 \%$ of whom are females. This paper presents findings on this experiment using 1,020 responses in a sample survey. Result showed that a significant of clients have improved their religious observations such as prayers and fasting. Results of the econometric models showed that household income, productivity of crops and livestock, expenditure and employment increased significantly due to the influence of changed behaviour and availability of micro-finance. Clients stated that the micro-investment had provided better organisation of their economic activities. Finally, the Islamic micro-investment programme appears to spur more ethical and economically desirable behaviour leading to poverty alleviation.
\end{abstract}

Keywords: Micro-finance and impact, Islamic finance, Rural development financing, Bangladesh, Behavioral changes.

JEL classification: G21.

\section{Introduction}

Microcredit is now a well established poverty alleviating programme which is being implemented in many parts of the world to address different development activities. This is especially so in Bangladesh the birthplace of the well-known initiative by Nobel laureate Professor Rahman. Besides providing credit facilities, all such institutions also provide training for skill development and self employment of the poor. Unfortunately, all these institutions provide interestbased credits and the rate of interest is often exorbitantly high, to commensurate with the risk in micro-finance lending.

\footnotetext{
${ }^{1}$ Note from editors: This paper is one of three best papers selected by a review panel of three professors at a Symposium held in November, 26-28, 2008 in Melbourne, Australia. The Symposium was funded by the Australian Research Council grant, 2007-2009/10, for research on Islamic Banking and Finance.
} 
The interest rates for institutional sources vary from $15-2 \%$, while those for the non-institutional sources range from 33 to 120 per cent (Mahmood, 2006). Sometimes the interest rates of non-institutional sources may even be $120-140 \%$. Mahmood also mentioned that the poor do not have any surplus production hence accumulation of capital is very difficult and sometimes impossible for them. On the contrary, owing to the absence of access to productive assets, lack of skills, low-level literacy, malnutrition and absence of an organization of their own, the rural poor fall into the poverty trap (Jaim, 1986). Besides, there are hardly any credit facilitating institutions that care about the ethical development of the rural poor to change their behaviour consistent with a disciplined approach to economic activity. Business behaviour and ethics are interrelated since the disciplined approach needed for good economic management is also seen as founded in ethically consistent behaviour.

Considering the above mentioned factors, Islami Bank Bangladesh Limited (IBBL) launched the Rural Development Scheme (RDS) in 1995. The main objective of this scheme is to alleviate rural poverty by providing shari'ah based small capital micro investment finance to the agricultural and rural sector for generating employment and raising income of the rural poor. The scheme also provides welfare, moral and ethical services to the rural people of the country. Presently, the scheme is being implemented through 129 branches covering 10,023 villages in 60 districts. Some 0.52 million group members are covered: $94 \%$ are females.

The Bank has a plan to double the activities of RDS within two years. However, before expanding in to the new areas, an assessment of the achievement of the project in terms of its impact on income, livelihood and moral/ethical development of the rural people is done. It may be mentioned here that although thousands of NGOs are working in the country with a view to alleviating poverty but the rural poor are still in the vicious circle of poverty and they have little hope of getting out of poverty in the near future. Besides, none of them care about ethical and moral development of the clients but IBBL microfinance is giving especial emphasis to changing behaviour, which aspect is its distinctive difference. Therefore, this study will also assess the moral and ethical changes of the clients and its impact of on their income and livelihood.

\section{Literature Review of Microfinance Impact Studies}

Previous studies on the impact assessment of microcredit programmes in Bangladesh have been narrow in their focus. PKSF (2005) studied the impact of micro-credit on the members of partner organizations of PKSF and found that absolute poverty was reduced by $9 \%$ during 1991 to 2000; moderate poverty declined by $5 \%$ during 2000 to 2004. Chowdhury and Bhuiya (2004) examined the impact of credit programme on the Bangladeshi borrowers under the BRAC projects and found positive impacts on human well-being, survival rate and schooling of children. Amin, Rai and Ropa (2003) conducted a study on the 
microcredit clients of Grameen Bank, BRAC and ASA. They observed that the micro-credit programme was more successful to reach the poor, but less successful to reach the vulnerable poor. Zaman (2001) assessed the impact of microcredit on poverty alleviation and women empowerment. He found positive impact on income, decision making ability and in reducing gender disparity. Bangladesh Institute of Development Studies (BIDS) conducted impact study on the microcredit borrowers under the partner organizations of PKSF. This study showed positive impact on the income of microcredit participants in comparison to non-program participants (BIDS, 2001). Khandker (2000) assessed the impact of microcredit on saving and found that microcredit increased voluntary saving, which was more pronounced in the cases of women than men.

However, all of these studies simply assessed the impact of interestbased microcredit programmes which did not consider shari'ah (Islami rules and regulations) related lending in investment and none of them assessed moral and ethical development of the clients. This study assessed these aspects of microfinance undertaken by the clients of rural development scheme functioning across the country. Unlike other microcredit programmes, this scheme emphasised clients' ethical and moral development activities in its microcredit programme. Therefore, this study assessed a different type of microcredit programme than the conventional ones, using modern econometric techniques.

Another point is that the size of the rural households in Bangladesh is generally large and they have a low level of literacy. Rural development is hampered due to lack of credits, lack of training, weak infrastructure and poor transport systems. The weak resource base coupled with a faster growing population is aggravating the poverty level of the country. Determination of the above factors which are most relevant in explaining poverty alleviation will have important implications for refining microfinance policy. This will also help to locate appropriate clients for the RDS-microfinance. Therefore, the other objective was to examine the linkage between clients moral and ethical behavioural changes as well as their income and demographic and investment factors.

\section{Methodology and Data}

\section{A. Conceptual Framework}

In this study, it was observed that the beneficiaries are mainly rural poor having very limited access to education and institutional credit and they also have low command over productive resources Due to their inability to meet the collateral requirement, the rural poor cannot start up productive activities even though they may have the adequate skills for pursuing income-generating activities. Because of their low level of income, they cannot even fulfill their consumption needs properly and ultimately they have to lead a lower quality of life. In such circumstances, microcredit programme may support the poor in reducing their poverty by creating both direct and indirect benefits. 
Under microcredit programmes, borrowers can take investment without providing collateral from the microcredit providers. The amount of investment they receive from the providers increases their financial ability to invest more into income generating activities. Microcredit programmes also provides opportunity to generate employment for the poor in the locality. By participating in income generating activities under microcredit, rural poor may have more earnings from activities that directly add to their income.

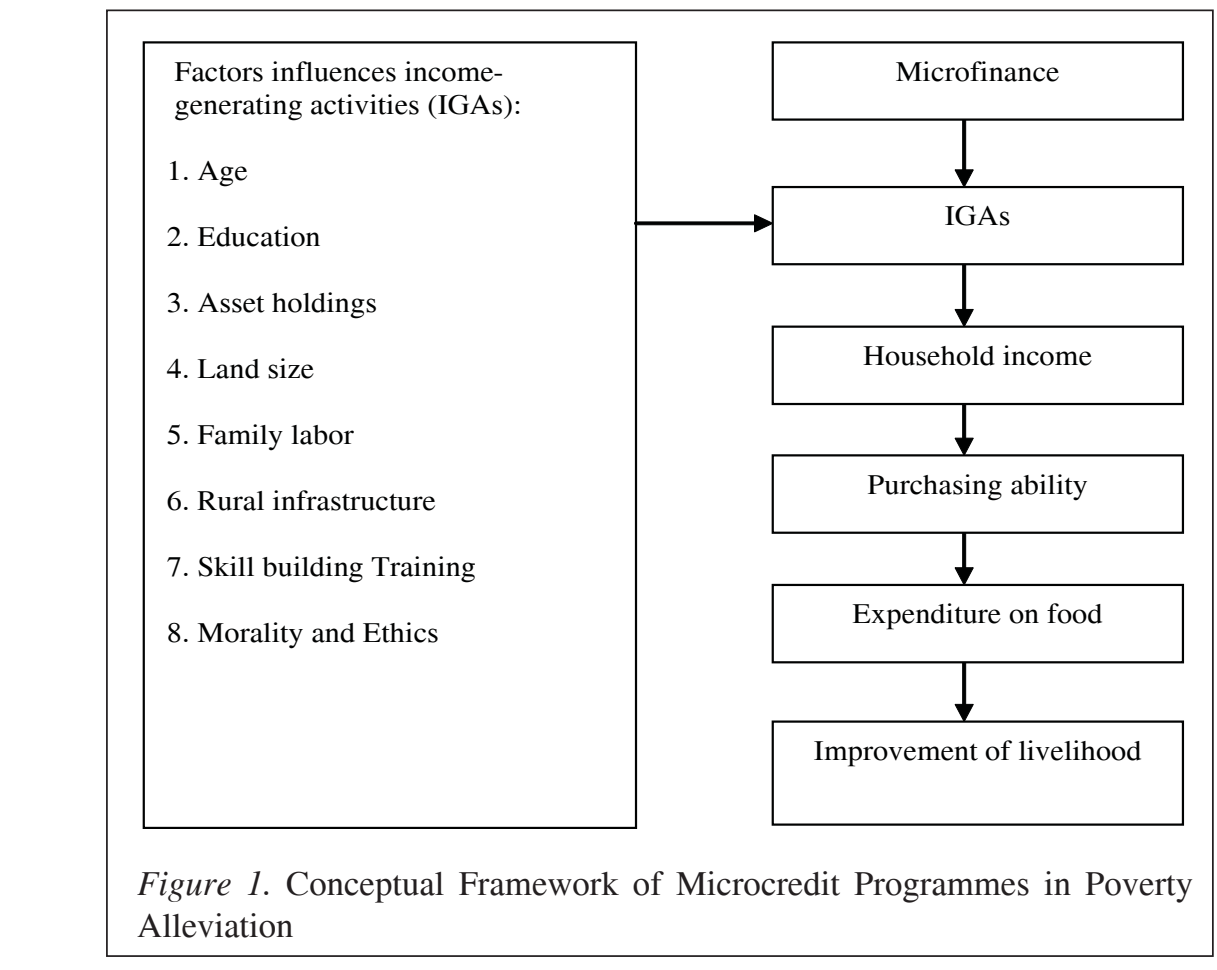

This increased income would ultimately increase their purchasing ability. More purchasing ability would enable them to spend more on food, thus, leading them to higher quality of living. The conceptual framework of microcredit in alleviating poverty is shown in Figure 1.

Besides income, there are other factors which are related to well-being of the borrowers. It is imperative to enhance human capital as it is deeply related to the well-being of the borrowers. Therefore, the programme provides training and non-formal education to the borrowers, hoping that training and education will enhance their level of skills in performing income-generating activities. Therefore, borrowers' age, education and experiences need to be considered carefully in choosing participants because decision-making ability may largely be influenced by such factors. Factors like household's asset will increase the ability of the borrowers to invest in income generating activities. Household 
asset also helps in increasing income earnings for them. In addition, it is difficult for the poor households to hire labour for operating income generating activities. Thus, they largely depend on family labour for pursuing income-generating activities. Due to the microcredit programme, they have the opportunity to utilize their manpower for productive purposes. Inadequacy of rural infrastructure is one of the major obstacles for development of Bangladesh. Rural poor have very limited access to infrastructural facility and this hampers their economic activities. Initiative to establish rural infrastructures (such as rural markets, roads etc.) under the microcredit programme may help them to accelerate their economic activity. Access to infrastructure facility and its proper utilisation will increase the ability of rural poor in pursuing their income generating activities (IGAs). Training and non-formal education of borrowers can enhance their level of skills in performing income generating activities. Therefore, the RDS programme also provides training and non-formal education to the clients.

Ethics and moral development is an important factor for developing human capital which is deeply related to the well-being of the clients. As RDS investment is collateral free, therefore, clients with good ethics and moral behaviour as determined by the field officer would indirectly act as collateral to get their investment back and also to invest the borrowed money to the proper income generating activities.

\section{B. Model Specification}

Literature shows that different techniques such as Descriptive Analysis, Ordinary Least Square (OLS), Weighted Least Square (WLS), Linear Programming (LP), and Simultaneous Equation Systems (SES) had been used by researchers in order to estimate the effect of microcredit on the various outcomes such as income, consumption and saving etc. Khandker (2000) estimated a conditional demand equation to assess the effect of microcredit on the economic outcomes, such as saving. The researcher used OLS estimation technique, using log in both sides, for this study which is as follows:

$$
Y_{i j}=\alpha_{0}+\beta_{i} \sum_{j=1}^{n} X_{i j}+\delta I_{i j}+\varepsilon_{i j}
$$

where,

$I=$ amount of credit taken by the borrower,

$Y=$ household income,

$X_{i j}=$ a vector of exogenous characteristics (such as age or education of household head)

$\beta$ and $\delta$ unknown parameters, and

$\varepsilon_{\mathrm{ij}}$ error component in the equation.

In this study, Ordinary Least Square (OLS) regression was used to assess the effect of microcredit on the dependent variables such as income, saving, and expenditure. The models were specified as: 


\section{Households Income Model}

$$
Y=\alpha_{0}+\beta_{1} X_{1}+\beta_{2} X_{2}+\beta_{3} X_{3}+\beta_{4} X_{4}+\delta I+\beta_{5} X_{5}+\beta_{6} X_{6}+\mu_{1}
$$

where,

$\mathrm{Y}=$ amount change ${ }^{2}$ of annual income of the household,

$\mathrm{I}=$ amount of investment taken by the borrowers in 2006,

$\mathrm{X} 1$ = total land size,

$\mathrm{X} 2$ age of the borrowers dummy (above 40 years of age is 1 and 0 otherwise),

$\mathrm{X} 3$ = education dummy (up to 5 years of schooling is 1 and 0 otherwise), $\mathrm{X} 4$ = number of family members engaged in income generating activities, $\mathrm{X} 5=$ distance of branch from the clients places (up to $10 \mathrm{~km}$ is 1 and 11 to $16 \mathrm{~km}$ is 0 ),

$\mathrm{X} 6=$ ethics and moral $^{3}$ of the clients,

$\beta_{1}$ and $\delta$ are the coefficients of the variables to be estimated, and

$\alpha_{0}$ constant for the equation and $\mu_{1}$ error term for the equation.

\section{Estimation of Well-being Based on the Clients' Opinion}

The Logit model was applied to find out the probability level that the clients would be well-off due to the influence of particular explanatory variable. In the Logit model, dependent variable "clients' well-being" had two categories such as "borrowers were well-off" under the programme coded as one and otherwise coded as zero.

Researchers who had used the logit model to assess the effect of microcredit programmes on loan utilization, awareness towards living-standard, and women empowerment had found positive effects of microcredit (Begum, 1998; and Zaman, 2001). Different studies used different dichotomous dependent variables in the logit model for example; Begum (1998) used awareness of the borrowers; Zaman (2001) used women's empowerment. In this study, the researcher used "borrowers' well-being" as the dependent variable which was divided into two categories: (i) borrowers were well-off, and (ii) borrowers were not well-off.

The model can be represented as follows:

$$
\begin{aligned}
& \operatorname{Ln}\left[P_{i} /\left(1-P_{i}\right)\right]=\beta_{0}+\beta_{3} E D U+\beta_{4} F M I G+\beta_{5} D B R+\beta_{6} D O M \\
& +\beta_{7} S F E+\beta_{8} E H C+\beta_{8} E A M C+\mu
\end{aligned}
$$

where,

$\mathrm{Pi}=$ probability that borrowers were well-off,

$1-\mathrm{Pi}=$ probability that borrowers were not well-off,

$\mathrm{EDU}=$ education dummy for the clients (up to 5 years of schooling is 1 ,

0 otherwise),

${ }^{2}$ Income of the year 2006 - Income of the year clients joined in RDS.

${ }^{3}$ Ethics and Moral of the Clients' is defined in Section 3.6 
$\mathrm{FMIG}=$ no of family members involved in income generating activities, $\mathrm{DBR}=$ distance of branch from borrower's place (dummy, up to $10 \mathrm{~km}$ distance is 1 and 11 to $16 \mathrm{~km}$ is 0 ), DOM = duration of membership (Years), $\mathrm{SFE}=$ share of food expenditure to the total expenditure (\%), $\mathrm{EHC}=$ expenditure on health care (taka), $\mathrm{EAMC}=$ ethics and moral $^{4}$ of the clients. and $\beta_{0}=$ constant, $\beta_{\mathrm{i}}=$ coefficient to be estimated and $\mu=$ error term.

\section{E. Estimation of Ethical and Moral Change Based on the Clients' Opinion}

The Logit model was selected in this study to find out the probability level that the clients would be better off due to the influence of particular explanatory variable. In the logit model, the dependent variable (clients' ethical and moral development) had two categories such as clients being "ethically and morally become well-off" under the programme coded as one and otherwise coded as zero.

Specifically model can be written as:

$\operatorname{Ln}\left[P_{i} /\left(1-P_{i}\right)\right]=\alpha_{0}+\beta_{1} E D U+\beta_{2} D B R 1+\beta_{3} A G E+\beta_{4} D O M+\mu$

where,

$\mathrm{Pi}=$ probability that clients' were ethically and morally well-off,

$1-\mathrm{Pi}=$ probability that borrowers were not ethically and morally well-off, EDU $=$ education dummy (up to 5 years of schooling is 1,0 otherwise),

$\mathrm{DBR}=$ distance of branch from borrower's place dummy (up to $10 \mathrm{~km}$ distance is 1 and 11 to $16 \mathrm{~km}$ is 0 ),

$\mathrm{AGE}=$ age of the borrowers dummy (above 40 years of age is 1 and 0 otherwise),

$\mathrm{DOM}=$ duration of the membership (years), and

$\alpha_{0}=$ constant,$\beta_{\mathrm{i}}=$ coefficient to be estimated and $\mu=$ error term.

\section{F. Estimation of Ethics and Moral of the Clients}

Opinions were sought from the clients about their awareness and practice of 10 different religious activities. Table 2.1 shows the different religious activities of the clients. A four-point Likert scale was used to evaluate the borrowers, moral and ethical development i.e. each statement had four options, which were regular, very often, very rare and not at all.

The points were summed up from each 10 statements and the total score obtained by each borrower were divided by the highest score of seventy-five in order to create an index of acceptability towards effectiveness of the microcredit programme. The borrowers who received scores less than $70 \%$ percent were

${ }^{4}$ Ethics and Moral of the Clients' is defined in Section 3.6 
coded as zero otherwise coded as one. Borrowers performance was considered satisfactory when they scored $70 \%$ or above. Therefore, in this study, borrowers' moral and ethics was evaluated based on the score of $70 \%$ or above. Mahmud (1999) created an acceptability index towards effectiveness of ADIP programme and the borrower who received scores $70 \%$ or above was coded as one to indicate that they were well-off under the ADIP's microcredit programme, otherwise coded as zero. Begum (1998) created an awareness index and the borrowers who received a score $50 \%$ was coded as one in order to indicate that awareness level increased toward their living-standard otherwise coded as zero.

Logit model was chosen in this study to find out the probability level that the borrowers would be morally and ethically well off due to the influence of particular explanatory variable. In the logit model, dependent variable 'clients moral and ethical development' had two categories such as 'clients morally and ethically well-off' coded as one and otherwise coded as zero.

\section{Table 1}

Religious Activities Performed by the Clients

\begin{tabular}{lcccc}
\hline \multicolumn{1}{c}{ Statements } & Regular & Very often & \begin{tabular}{c} 
Very rare \\
\multicolumn{1}{c}{ Score (no.) }
\end{tabular} & $\begin{array}{c}\text { Not at } \\
\text { all }\end{array}$ \\
\hline Saying prayer & $10(0)$ & $6(4)$ & $4(6)$ & $0(10)$ \\
Know how to recite Holy Quran & 405 & 204 & 170 & 215 \\
Reciting Holly Quran & 643 & - & - & 351 \\
Fasting & 139 & 164 & 136 & 655 \\
Inviting towards Islamic activities & 807 & 79 & 21 & 87 \\
Involvement with dowry & 324 & 289 & 311 & 70 \\
Maintain Parda & 033 & - & - & 961 \\
Involve with interest & 596 & 191 & 109 & 98 \\
Misunderstanding with husband & 111 & 71 & 29 & 783 \\
Involvement with social activities & 049 & 29 & 11 & 905 \\
\hline
\end{tabular}

Note: Figure in the parentheses are the score for dowry, interest and misunderstanding with husband.

\section{G. Justification of Retaining Variables in the Study}

The factors which are responsible for the impact of microcredit on the rural poor have been reviewed. Girish and Mehta (2003) and Asanoy (2004) observed that age of the family head and family size were an important factor for economic decision such as production and consumption. Latif (2002) also observed that family size had influence on consumption and calorie intake of rural Bangladeshi households. Shrestha and Shivakoti (2003) mentioned that family labour was one of the important human capitals. Therefore, rural farmers are largely depended on their family labour for pursuing economic activities. Khandker (2000) reported that microcredit programmes had increased production, consumption, 
and employment opportunity and reduced informal borrowing among the borrowers and it had also increased the ability of the poor borrowers to save regularly for building financial and physical capital. Asanoy (2004) indicated that educated borrowers had higher level of knowledge and skills as compared to less educated borrowers in case of performing their economic activities. Latif (2002) observed that the establishment of rural infrastructure had reduced production cost, transportation cost and it had created easy access to markets for inputs and outputs. Shrestha and Shivakoti (2003) mentioned that physical infrastructure facilities helped in distributing inputs and output, adding value and enhancing production.

It is hypothesized that all of these variables would influence households' livelihood, therefore, age, education, family size, financial capital, savings and asset base has been considered in this study as important factors of livelihood.

\section{H. Sources of data}

The primary data were directly collected from the field, during December 2006 to April 2007, through interviewing 1020 clients across the country. The impact of investment on ethics and moral of the RDS client's were our major interest therefore assessment was made comparing the clients' present position (31 December 2006) with their base (information at the time of becoming member).

Using the stratified sampling approach, the selection procedure for the RDS clients considers several factors, and involves multiple stages. The first step involves dividing the RDS executing branches of IBBL into seven administrative zones defined by IBBL. In order to capture diversity, the 34 branches were randomly selected from seven administrative zones following the probability proportionate to size (PPS) method (Appendix-1; Bangladesh Map).

Two subsequent stratifications were made within each branch on the basis of time of becoming client of RDS. Of the selected branches, 30 RDS investment clients from each branch, was randomly selected. So, the total clients for the study were 34 x $30=1020$ (Table 2 ).

Table 2

Distribution of the Samples

\begin{tabular}{|c|c|c|c|c|c|}
\hline Sl. No. & $\begin{array}{c}\text { Sample } \\
\text { Types }\end{array}$ & \multicolumn{2}{|c|}{ No of Branch } & $\begin{array}{c}\text { Sample per } \\
\text { Branch }\end{array}$ & Total Sample \\
\hline \multirow{8}{*}{1} & \multirow{8}{*}{ Clients } & Dhaka north & 4 & \multirow{8}{*}{30} & \multirow{8}{*}{1020} \\
\hline & & Dhaka south & 3 & & \\
\hline & & Chittagong & 3 & & \\
\hline & & Comilla & 5 & & \\
\hline & & Bogra & 9 & & \\
\hline & & Khulna & 8 & & \\
\hline & & Sylhet & 2 & & \\
\hline & & Total branch & 34 & & \\
\hline
\end{tabular}


The data were collected from the clients using a set of semi-structured pre-tested questionnaire prepared for the purpose. A total of 34 well trained enumerators (one for each branch), have collected the data under the supervision of the researcher. The data were coded and entered in to the SPSS (Statistical Package for Social Scientists), Version 12.

\section{Analytical Frame Work}

The major concern of this study was to assess the impact of RDS investment client. So, comparison was made between the status at present (up to December 2006) and at joining (joining time of the individual clients) on a cross sectional basis. In total 1020 clients were interviewed. Of them, the interview of 26 clients were incomplete and hence were dropped from the analysis. The rest of the sample (994) were analysed and the conventional tabular method was used in describing and comparing the performance of the RDS clients. The responses were expressed in terms of percentage/frequencies. Besides, in order to meet up the objectives the collected data were analysed economically, statistically and econometrically.

\section{Results and Discussion}

The study was intended to explore the true picture of ethical and moral development of the clients' livelihood and its impact on poverty alleviation through micro-investment of the RDS. The results are presented below:

\section{A. Behavioural and Ethical Information of the Respondents}

Religious behaviour and ethical development of the clients was one of the important objectives of RDS programme. Therefore, clients' present religious performances were plotted in Figure 2. Result shows that most of the clients do fasting, while almost $85 \%$ clients maintained parda. Although, $85 \%$ clients avoid taking interest, this information is dubious as $15 \%$ clients have involvement with other interest based NGO's. The reason of providing misinformation could be that some of the clients are not still clear about the difference between interest and profit.

\section{B. Changes in Family Income}

Effort was taken under this microinvestment programme to increase clients' family income by investing their borrowed money to different income generating activities. Table 3 shows that on average clients' income has increased by more than $33 \%$ from joining in the RDS up until 2006. The highest income change (6763 Tk. /year) was observed for small business which was followed by income from services (4615 Tk. /year). The crop sector income has also significantly increased but highest change was observed for small business which implied that clients preferred investing money into the business sector. 


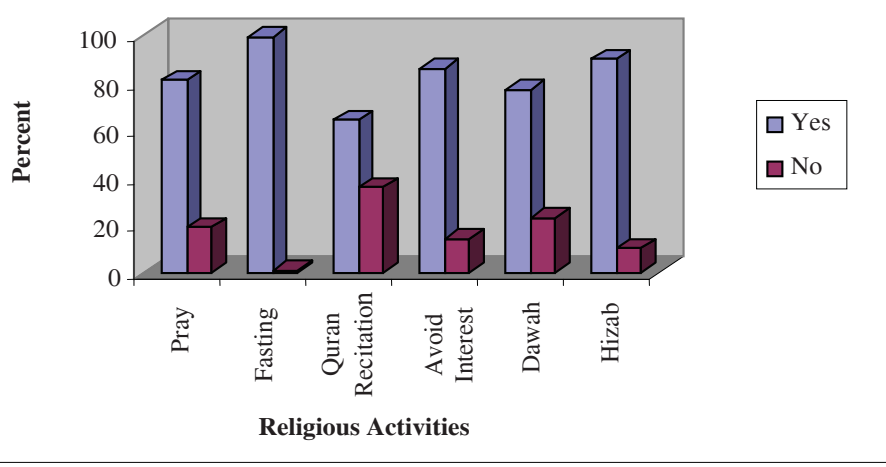

Figure 2. Distribution of Clients by Religious Activities

Table 3

Annual Income Generation of the Households by Sources

\begin{tabular}{|c|c|c|c|c|c|c|}
\hline \multirow{2}{*}{ Source of Income } & \multicolumn{2}{|c|}{$\begin{array}{l}\text { Household income } \\
\text { (Tk / year) }\end{array}$} & \multicolumn{2}{|c|}{ Change of Income } & \multicolumn{2}{|c|}{$\begin{array}{c}\text { Level of } \\
\text { Significance }\end{array}$} \\
\hline & Present & Joining & Taka & Per cent & t-value & Sig. \\
\hline Crops & 13118 & 10993 & 2125 & 19.33 & 3.188 & 0.001 \\
\hline Fruits selling & 1629 & 977 & 652 & 66.73 & 3.641 & 0.000 \\
\hline Vegetable & 2109 & 1464 & 645 & 44.06 & 3.865 & 0.000 \\
\hline Livestock & 4070 & 2841 & 1229 & 43.26 & 5.463 & 0.000 \\
\hline Poultry & 1669 & 1195 & 474 & 39.67 & 2.507 & 0.012 \\
\hline Small Business & 32061 & 25298 & 6763 & 26.73 & 4.015 & 0.000 \\
\hline Labour Selling & 13617 & 11003 & 2614 & 23.76 & 6.509 & 0.000 \\
\hline Service Income & 14827 & 10212 & 4615 & 45.19 & 5.564 & 0.000 \\
\hline Others & 9927 & 5751 & 4176 & 72.61 & 2.222 & 0.038 \\
\hline Total & 93027 & 69734 & 23293 & 33.4 & & \\
\hline
\end{tabular}

\section{Impact of RDS on Clients Religious Activities}

In addition to the poverty alleviation the microinvestment program has taken initiative to increase the clients' awareness on religious activities. Therefore, in this study attempt was made to assess the influence of RDS on clients' awareness on religious activities. Table 4 shows that a significant number of clients $(21 \%)$ have started praying after joining RDS programme. Besides, a significant number of clients have started practicing some other religious activities like, reciting Holly Quran, inviting others to follow Islamic activities and avoid taking interest. 
Table 4

Awareness on Religious Activities of the Clients of RDS

\begin{tabular}{lcccc}
\hline \multirow{2}{*}{ Indicators } & At Present & At Joining & \multicolumn{2}{c}{ Change Status } \\
\cline { 2 - 5 } & Frequency & Frequency & Frequency & Percent \\
\hline Regular prayer & 779 & 643 & 136 & 21.15 \\
Know how to recite Holy Quran & 643 & 600 & 43 & 7.17 \\
Reciting Holy Quran & 339 & 273 & 66 & 24.18 \\
Fasting Regularly & 907 & 880 & 27 & 3.07 \\
Inviting towards Islamic activities & 924 & 870 & 54 & 6.21 \\
Involvement with dowry & 033 & - & - & - \\
Wearing Hizab & 896 & 885 & 11 & 1.24 \\
Not involve with interest & 883 & 814 & 69 & 8.48 \\
Misunderstanding with Husband & 089 & - & - & - \\
Involvement with any local crime & 007 & - & - & - \\
\hline
\end{tabular}

\section{Results of Ordinary Least Square (OLS) Estimation of the Model}

One of the prime objectives of the study was to assess the factors influencing households' income, expenditures, well-being and ethical and morals of the - clients. The Ordinary Least Square (OLS) technique was used to estimate the model for assuming the effect of different factors of the model. If the regression equation estimation of similar functions involve more variables, the model would have suffered from low degrees of freedom and multicollinearity problems resulting in inefficient estimates. Therefore, multicollinearity was tested and the outcome of some independent variables not being significant could be the effect of multicollinearity. The regression model was re-estimated; dropping some variables whose level of significance was very low. The results were significantly improved and hence have been interpreted.

\section{E. OLS Results for the Household Income Model}

It was expected that the amount of investment taken by the borrowers would increase their household income. Therefore, this study examined the influence of microinvestment on the households' income. However, household income does not depend on only one factor like amount of investment. It also depends on the other socioeconomic factors. That is why, variables like borrower's age, borrower's educational background, involvement of family members in farming, total land size of the households, distance to branch from the borrowers' place and ethics and moral of the clients were considered as independent variables. 
Table 5 shows the results of OLS for the households' income. As can be seen from the statistics, the sign of all the variables are plausible but only four of them namely, borrowers' age, amount of investment taken by the borrowers, number of family members involved in earning and clients' ethics and morals had positive and significant influence on the household income. The value of $\mathrm{R}$-square was 0.693 . It indicates that about $69 \%$ of the total variation of the dependent variable was explained by the independent variables.

It was found that the amount of investment taken by the borrowers had a positive and significant influence on the household income. This collateral free investment-money had increased their opportunity to start up income generating activities. It had also increased their ability to invest more on the existing economic activities resulting in more earnings from their investment. All these reasons had assisted them in increasing their household income. Household income would increase by 1.21 taka because of receiving additional one unit of investment by the borrower from the microinvestment providers.

The study showed that the borrowers' age variable was positively and significantly related with household income. As age increases, borrowers acquire more experiences which would ultimately assist them to increase their household income level. Many researchers used age as independent variable in their regression analysis in order to assess its influence on borrowers saving, agricultural production, household income and consumption (Khandker, 2000; Amin et al., 2003) and found significant influence.

This study shows that the number of earning family members' had positive and significant influence on their households' income. This result implied that higher the number of earning family members, the higher the family income. This expected result is also supported by Mahmood (2006).

Education did not show any significant influence on household income as there was small variation of education among the clients. Result showed that more than $90 \%$ of the borrowers had schooling of less than five years. However, the variable had a positive sign. This indicates that education might influence their income level but it required more time and more educational facilities for the borrowers to realize the effect of education on income.

The results showed that the distance of branch from borrowers place had no significant effect on the households' income level. However, the sign for the dummy variable (10 to $16 \mathrm{~km}$ distance from branch) was negative meaning that further increasing distance between branch and borrowers' place would decrease the income earning opportunities. It is worth mentioning here that ethics and morals had positive contribution on household income. This result is not unlikely as it is assumed that the clients who are bearing good moral and ethical characters are honest and sincere enough, so they did not divert their borrowed money to any unproductive sector. Besides, they are sincere enough in their activities and hence may have generated more income. 
Table 5

Estimated OLS Results for the Household Income

\begin{tabular}{lccc}
\hline Variables & Co-efficient & t-value & Sig \\
\hline Constant & 4.079 & 38.384 & $0.000^{* *}$ \\
Log of Investment taken in 2006 & 1.210 & 2.612 & $0.019^{* *}$ \\
Log of total land size & 0.101 & 0.408 & 0.684 \\
Log Number of earning family members & 1.160 & 1.990 & $0.024^{* *}$ \\
$\begin{array}{l}\text { Distance of branch dummy (up to 10 km is 1 and 11 } \\
\text { to 16 km is 0) }\end{array}$ & -0.030 & -0.115 & 0.108 \\
Borrower's age dummy (above 40 years) & 0.201 & 2.646 & $0.018^{* *}$ \\
$\begin{array}{l}\text { Education dummy (up to 5 years schooling is 1 and } \\
\text { 0 otherwise) }\end{array}$ & 0.120 & 0.738 & 0.460 \\
Ethics and Moral (Dummy) & 0.090 & 1.847 & $0.055^{*}$ \\
\hline
\end{tabular}

R-squared: 0.603

Note: ** Significant at $1 \%$ level, and * Significant at $5 \%$ level.

\section{F. Results of the Logit Model for Clients' Well Being}

The logit model was selected in this study to find out the probability level that the clients would be well-off due to the influence of particular explanatory variable. In the Logit model, dependent variable "clients' well-being" had two categories such as "borrowers were well-off" under the program coded as one otherwise coded as zero. The rural poor had to lead a low quality of life. It is expected that the microfinance programme would bring a positive change in the overall livingstandard of the borrowers by improving their economic activities. Therefore, an attempt was made to investigate the influence of socioeconomic variables on the dependent variable "borrowers welfare". Based on the borrowers' perceptions, the dependent variable was coded as one if the borrowers had answered welloff under the microinvestment programme, otherwise, it was coded as zero. the logit model was used in order to find out the probability level that the borrowers would be well-off due to the influence of a particular independent variable.

Table 6 shows that the duration of RDS membership, number of income generating family members, share of food expenditure to total expenditure, households health expenditure and clients ethics and morals had positive and significant contribution on clients well-being.

Table 6 shows that the Wald statistic for the variable "expenditure on health" was 3.03 and it was positively and significantly related to the dependent variable. This indicates that more expenditure on health care would increase the likelihood for the borrowers to be well-off. 
Due to the low level of purchasing ability, borrowers had to maintain a low level of expenditure indicating a lower quality of living. They had to struggle even to meet their expenditure on food items. The microfinance programme takes the effort to increase borrowers' ability to spend more on food items for better living. Table 6 shows that wald statistic for the independent variable "share of food expenditure to the total expenditure" was 5.746, and it was found significantly and positively related with the dependent variable.

It may be mentioned here that ethics and moral had positive contribution on clients' well-being. This result is not unlikely as the clients bearing good moral and ethical characters are honest enough so they did not divert their borrowed money to any unproductive sectors. Besides, they are sincere enough to their activities hence were better-off.

\section{Table 6}

Estimated Results of the Logit Model

\begin{tabular}{|c|c|c|c|c|c|}
\hline Variable & (B) & $\begin{array}{l}\text { Standard } \\
\text { error }\end{array}$ & $\begin{array}{c}\text { Wald } \\
\text { statistics }\end{array}$ & Sig. & $\begin{array}{l}\text { Odd ratio } \\
\operatorname{EXP}(\mathrm{B})\end{array}$ \\
\hline Constant & -0.954 & 0.823 & 1.344 & 0.246 & 0.385 \\
\hline Duration of membership & 0.238 & 0.062 & 14.64 & $0.000^{* *}$ & 0.788 \\
\hline $\begin{array}{l}\text { Education dummy (up to } 5 \text { yrs of } \\
\text { schooling is } 1 \text { and } 0 \text { otherwise) }\end{array}$ & 0.014 & 0.251 & 0.201 & 0.986 & 0.996 \\
\hline Income generating family members & 0.208 & 0.073 & 13.67 & $0.00^{* *}$ & 0.768 \\
\hline $\begin{array}{l}\text { Age of the clients dummy (up to } 40 \\
\text { yrs of age is } 1 \text { and } 0 \text { otherwise) }\end{array}$ & -0.060 & 0.556 & 0.011 & 0.916 & 0.942 \\
\hline $\begin{array}{l}\text { Share of food expenditure to the } \\
\text { total expenditure }(\%)\end{array}$ & 0.014 & 0.006 & 5.746 & $0.017^{* *}$ & 1.014 \\
\hline Health expenditure (taka) & 0.017 & 0.020 & 3.031 & $0.054^{*}$ & 1.010 \\
\hline Ethics and morals & 0.164 & 0.243 & 3.476 & $0.050^{*}$ & 0.846 \\
\hline \multicolumn{6}{|l|}{ Cox and Snell R square: 0.198} \\
\hline \multicolumn{6}{|l|}{-2log likelihood: 667.280} \\
\hline Overall accuracy: 82.8 & & & & & \\
\hline
\end{tabular}

Note: $* *$ Significant at $1 \%$ level and $*$ significant at $5 \%$ level.

\section{G. Results of the Logit Model for Assessing Clients Ethics and Moral}

It is expected that RDS program would bring a positive change in the ethical and moral development of the clients. Therefore, an attempt was made to investigate the influence of socioeconomic variables on the dependent variable "moral and ethical development". 
Table 7

Estimated Results of the Logit Model for Ethics and Moral

\begin{tabular}{lccccc}
\hline \multicolumn{1}{c}{ Variable } & (B) & $\begin{array}{c}\text { Standard } \\
\text { error }\end{array}$ & $\begin{array}{c}\text { Wald } \\
\text { statistics }\end{array}$ & Sig & $\begin{array}{c}\text { Odd ratio } \\
\text { EXP (B) }\end{array}$ \\
\hline Constant & 1.101 & 0.447 & 6.070 & $0.014^{* * *}$ & 3.008 \\
$\begin{array}{l}\text { Education dummy (up to 5 yrs of } \\
\text { schooling is 1 and 0 otherwise) }\end{array}$ & 0.633 & 0.165 & 14.076 & $0.000^{* *}$ & 0.531 \\
$\begin{array}{l}\text { Age of the Clients dummy (up to } \\
\text { 40 yrs of age is 1 and 0 otherwise) }\end{array}$ & 1.424 & 0.366 & 15.136 & $0.000^{* *}$ & 0.241 \\
$\begin{array}{l}\text { Membership Duration (years) } \\
\text { Distance of branch (up to10 km } \\
\text { distance is 1 and 0 otherwise) }\end{array}$ & 0.102 & 0.032 & 10.028 & $0.002^{* * *}$ & 1.108 \\
Cox and Snell R square: 0.178 & -0.402 & 0.246 & 2.665 & 0.103 & 0.669 \\
-2log likelihood: 1241.76 & & & & & \\
Overall accuracy: 72.8 & & & & & \\
\hline
\end{tabular}

Note: $* *$ Significant at $1 \%$ level and $*$ significant at $5 \%$ level.

Based on the borrowers' perceptions, the dependent variable coded as one if the borrowers were morally and ethically well-off under the microinvestment program and otherwise it was coded as zero. The logit model was used in order to find out the probability level that the borrowers would be morally and ethically well-off due to the influence of a particular independent variable.

Table 6 shows that the educational level, age and membership duration had positive and significant contribution on clients' ethics and moral development. This result implies that elderly and educated clients who have several years' involvement with this RDS programme have ethically and morally been more developed than the young and illiterate new clients.

\section{H. Clients' Opinion towards Micro-investment Programmes}

Clients' opinion about the benefit of microinvestment programmes on their skill, social and economic condition was assessed and organized them in Table 8. Results showed that microinvestment programme had brought positive changes in their skill and socioeconomic status. Of them, self confidence development, economic solvency, communication skill, and knowledge on business and religion practices are mentionable.

\section{Major Problems and Suggestions Stated by the Clients}

Like other credit programs, RDS microinvestment clients also face problems participating in the microfinance program. Their problems are diverse in nature and vary depending on time, space, socioeconomic aspects, and nature of the 
program. Success of the programs largely depends on identifying and solving the problems on time. Therefore, in order to improve the operations of the program, it is important to identify clearly the borrowers' problems.

Table 9 shows that majority $(90.65 \%)$ of the borrowers had problems with investment size. They mentioned that the amount of investment they had received from the micro-investment providers was inadequate for them to pursue their income generating activities (IGAs) smoothly.

\section{Table 8}

Impact of RDS on Clients skills Stated by the Clients

\begin{tabular}{clcccc}
\hline \multirow{2}{*}{ Serial } & \multirow{2}{*}{ Types of change } & \multicolumn{2}{c}{ Increased } & \multicolumn{2}{c}{ No change } \\
\cline { 3 - 6 } & & Frequency & Per cent & Frequency & Per cent \\
\hline 1 & Economic solvency & 775 & 77.97 & 219 & 22.03 \\
2 & Islamic practice & 240 & 24.14 & 754 & 75.86 \\
3 & Social dignity / Status & 211 & 21.23 & 783 & 78.77 \\
4 & Self confidence & 800 & 80.48 & 194 & 19.52 \\
5 & Business knowledge & 720 & 72.43 & 274 & 27.57 \\
6 & Communication skills & 785 & 78.97 & 209 & 21.03 \\
7 & Knowledge on business & 755 & 75.96 & 239 & 24.04 \\
& computation & & & & \\
8 & Confidence on & 596 & 59.96 & 398 & 40.04 \\
\hline
\end{tabular}

Table 9

Major Problems Stated by the Clients

\begin{tabular}{clc}
\hline Serial & \multicolumn{1}{c}{ Problems } & Per cent \\
\hline 1 & Amount of investment is very small & 90.65 \\
2 & Do not have any training programme & 85.60 \\
3 & Investment getting period is very long & 84.70 \\
4 & Gestation period for repaying investment is too short & 78.55 \\
5 & Insufficient time for meeting & 72.00 \\
6 & There is no place for organizing meeting & 70.65 \\
7 & Need to produce fake buying and selling voucher & 33.65 \\
8 & Tenants are ignored for getting investment & 26.08 \\
9 & No Islamic school for their children & 23.26 \\
10 & Woman has no control on their borrowed money & 15.66 \\
\hline
\end{tabular}

Lack of training facilities to upgrade their skills and technical and Islamic knowledge is also an important problem mentioned by $86 \%$ clients. About $85 \%$ respondents mentioned that a delay in receiving investment is also a problem which was followed by very short gestation period for repaying investment. 
Some respondents $(78 \%)$ mentioned that some times they needed to start repaying their borrowed money even before investing the money. Some clients $(33.65 \%)$ had to produce false voucher which is a clear violation of shariah. Besides, there is no Islamic school under this scheme which can teach Islamic knowledge to the children.

\section{Conclusion}

Microcredit is now a well established poverty alleviating programme which is being implemented across the world. All these institutions working in Bangladesh provide interest based credit which is straightway a violation of shari'ah. These institutions also do not care about the ethical aspects of the rural poor, although

it is obligatory, not only in business sector but also in all aspects of life. Business and ethics should be interrelated.

However, the microinvestment programme is to uplift the overall socioeconomic plight of the rural poor, which, in this case, cares about developing ethics and morals development of the clients as it can play a crucial role in alleviating poverty.

This assessment highlighted the achievement of ethics and morals of the clients and its contribution on poor people's livelihood and summary of the study findings, conclusion and policy implications are presented below:

Although, level of participation in religious activities by the clients has greatly been improved after joining RDS programme, there is still room to improve these activities, especially knowledge about interest, its consequence, and how to get rid of it. Therefore, a weekly meeting or frequent lectures may be organized regarding this issue.

Results showed that most of the clients utilized their borrowed money but the reality is that not all clients invested their borrowed money to income generating activities. Instead, some of them utilised their investment in house repairing, children's marriage ceremony and furniture purchase etc. Therefore, proper monitoring and supervision should be done to develop their morals and ethics so that they use their money in income generating activities.

It was observed that some field supervisors do not properly practice the Bai-muajjal mode; which is a clear violation of shari'ah so, necessary measures have to be taken to develop their moral and ethics so that they do not violate shari'ah.

- Mudaraba mode of investment may be practised with some selective good clients, even if in some cases this mode does not bring any profit for the scheme so that the clients and person concerned would find the difference between conventional (interest based) and Islamic microfinance. Incorporating this mode in place of Bai-muajjal mode would reduce shari'ah violation. 
- $\quad$ Poor borrowers are not aware of the modern technology. They depend much on the traditional method of farming resulting in low production. Therefore, provision should be made to provide demand-led and effective training on different aspects of on-farm and off-farm activities, credit management, environmental pollution, nutrition, health care and ethical development.

- It was observed that field supervisors are not well trained up and hence they found it difficult to motivate the rural people toward RDS and also to manage the RDS centres. Frequent training should therefore, be organised for improving the field supervisors' knowledge, skill, moral and ethical values.

- RDS organises weekly meetings in each centre but effectiveness of the meetings cannot be maintained due to shortage of time. Therefore, duration of centre meeting time has to be increased so as to make those meetings effective.

- $\quad$ Model estimation results showed that branch distance from RDS clients place (11 to $16 \mathrm{~km}$ ) has a negative impact on clients' income and wellbeing. Although this result is not significant, it is alarming. Therefore, branch command area for RDS programme should not be expanded beyond the 16 kilometre range.

- The number of RDS clients is sharply increasing higher although the average rate of dropout (11\%) is also alarming. The reason for dropout is not yet known therefore, proper selection of clients is very important and monitoring should be increased to reduce the rate of dropout.

Author information: Dr. M. Miazur Rahman is the Director of the Islami Bank, Bangladesh Limited (IBBL).

\section{References}

Amin S., Rai A.S. and Ropa G. (2003) Does microcredit reach the poor and vulnerable? Evidence from Northern Bangladesh. Journal of Development Economics, 70, 59-82.

Asanoy, A. (2004). Effects of agricultural credit and microfinance on expenditure patterns in Yemen (Unpublished doctoral dissertation). Universiti Putra Malaysia, Selangor, Malaysia.

Bangladesh Institute of Development Studies (BIDS). (2001, October). Final Report on BIDS Study on PKSF's Monitoring and Evaluation System (MES) Dhaka.

Begum, R.A. (1998). A comparative study on the status of awareness and potential of credit receiver and credit non-receiver rural women in selected areas of Dinazpur district of Bangladesh ( Unpublished master' thesis). Agricultural University, Mymensingh, Bangladesh. 
Chowdhury, A. M. R., and Bhuiya, A. (2004). The wider impacts of BRAC poverty alleviation programme in Bangladesh. Journal of International Development 16(3), 369-386.

Girish, M., and Mehta, P. (2003). Crop diversification: An empirical analysis on Kangra farms of Himachal Pradesh, India. Asia-Pacific Journal of Rural Development, 13 (2).

Latif, M.A. (2002). Income, consumption and poverty impact of infrastructure development. The Quarterly Journal of the Bangladesh Institute of Development Studies, 28 (3), 1-36.

Mahmood, T. (2006). Effectiveness of microcredit for poverty alleviation under agricultural intensification projects in Bangladesh. (Unpublished doctoral dissertation). School of Graduate Studies, University Putra Malaysia, Malaysia

Mahmud, K. T. (1999). Impact of credit on income and employment of women members of Savar Thana under world vision project (Unpulished master's thesis). Bangabandhu Sheikh Mujibur Rahman Agricultural University, Gazipur, Bangladesh.

PKSF (2005). Follow up monitoring and evaluation system (MES). HB Consultant Limited.

Shrestha, S. G. and Shivakoti, G. P. (2003). Prominent livelihood asset Pentagon within the analytical framework of irrigation system performance assessment. Asia-Pacific Journal of Rural Development, 13(1), 60-88.

Zaman, H. (2001). Assessing the poverty and vulnerability impact of micro-credit in Bangladesh: A case study of BRAC. (World Bank Policy Research Working Paper No-2445). Washington D.C.: World Bank. 